\title{
Biopolitical Commons in the Postdigital Era
}

\section{Carlos Escaño ${ }^{1}$}

Published online: 2 April 2019

(C) Springer Nature Switzerland AG 2019

Recovering the idea of a common world is not a form of utopian escapism. Quite the opposite. It is assuming a commitment to a reality that cannot be anyone's particular project and in which, whether we like it or not, we are always involved. (Garcés 2013: 14) (author's translation from Spanish ${ }^{1}$ )

\section{The Rise of Biopolitical Commons}

Global economic policies permanently try to enclose what is common to all of us and turn it into a commodified resource. In 18th and 19th century Europe emerging capitalism promoted the conversion of common lands into private hands through various means such as enclosure acts. Today, similar communal enclosures are generated in and around the world of ideas. A typical case in the point is academic publishing, where global intellectual property regime combined with postdigital changes in production, access, maintenance and distribution of knowledge has brought about tremendous economic, social, political and institutional crisis (Jandrić 2017; Jandrić and Hayes 2019). While there is a lot to be learned from history, postdigital cultures bring back the ancient concept of the commons with a fresh twist (Garcés 2013). Reaching beyond production of objects as commodities, we are now dealing with production of subjectivity (Hardt and Negri 2009). In this way, immaterial closure has become a biopolitical battlefield. 18th century objective: land; 21 st century objective: culture.

\footnotetext{
${ }^{1}$ Original text: Recuperar la idea de mundo común no es una forma de escapismo utópico. Todo lo contrario. Es asumir el compromiso con una realidad que no puede ser el proyecto particular de nadie y en la que, queramos o no, estamos ya siempre implicados. (Garcés 2013: 14)
}

Carlos Escaño

jcescano@us.es

1 University of Sevilla, Sevilla, Spain 
Following Marcuse's (1991) suggestion that the political needs of the society have become individual needs and aspirations, Marina Garcés (2013) (based on Pietro Barcellona) argues that globalization is a system that maximizes individualism and universalizes fragmentation of ownership and responsibility. Thus, neoliberal logic of globalization absorbs counter-cultural concepts and converts them into a homogeneous and hegemonic culture. Arguably, the best late 20th century example of this dynamic is relocation of development of digital technologies from US army laboratories to the hyper-capitalist start-ups of the Silicon Valley. As a result, counter-cultural leitmotifs such as openness and shared mentality which (somewhat paradoxically) flourished in American military-funded academic research centres during the 1960s have transformed into probably the most advanced neoliberal economy in the world (Jandrić 2017). Garcés (2013: 25) spells out a political formula which describes these new reifications of the common into the private, the universal into the particular: 'the particular is today of universal scope and the private is today what articulates the public space'.

In 1968 Garrett Hardin published the controversial article 'The Tragedy of the Commons' which supports neoliberal claims over the commons. Despite various criticisms (see, for instance, Aguilera-Klint 2012) Hardin shows concern for important issues such as the growth of world's population and proposes concepts useful for today's debate such as access, production, management, protection, conservation, and development of the commons. Semantically, the concept of the commons is based on a threefold tradition imbued in its historical discourse. Laval and Dardot (2014) trace the historical route from Aristotelian politics and ethics and analyse political literature where meanings, concepts and lines of thought are superimposed. In this analysis, the first tradition conceives the commons as a supreme purpose, where the overarching norm of the common good should provide the main guidance for action. The second tradition is of juridical origins and promotes specific world's common goods: atmosphere, water, knowledge, etc. The third tradition is of philosophical origins and focuses the debate to identification of the common with the universal (what is common to all) or with the vulgar (in Latin, vulgaris means that which belongs to common people). Etymologically, the concept of the commons is linked to the Latin concept of munus which denotes benefits, honours and advantages related to one's social position. Munus describes what takes for an individual to arrive to a certain social position and what is given in exchange; it is a dialectic between debt and gift. Under this etymological approach, the three semantic traditions can be understood more clearly: the first is theological, while the second and the third are intersubjective. However, all these understandings of the commons are subject to reciprocal nature of reward and commitment in the assumption of responsibility. In an etymological sense, our capacity to enjoy the commons depends on our responsibility and fair coexistence which guarantees that the commons can be enjoyed by all.

This conception of the commons creates a safety net in which subjects' commitment feeds into collective commitment and forms an individual as a part of the collective. All that is common (common goods to be attained, common goods we enjoy, or common goods in which we participate) is mediated by social interaction. Therefore, the commons result from social production necessary for one's social interaction and ulterior production (Hardt and Negri 2009): knowledge, languages, codes, affections, etc. Traditional views typically position the commons as a natural world outside society (see Hardin 1968). However, the commons are not an exogenous problem or an 
external fact: speaking about the commons, we are speaking about ourselves. In our postdigital age, therefore, commons do not situate humanity in separation from nature (as its exploiter or protector), but focus on interaction, care and cohabitation within a common world (Jandrić et al. 2019). This biopolitical understanding of the commons reaches beyond spheres of life such as land, air, plant, and animal life, or indeed the Internet, and includes constitutive elements of human society such as languages, habits, affections, codes (Hardt and Negri 2009).

\section{Biopolitical Production in Postdigital Times and Spaces}

The rising importance of immaterial economic production has created new postdigital concepts of work, generating various developments in areas such as affective and intellectual work and indeed all 'informational' practices that create concepts, symbols and desire, and the modes of their social interaction (Brea 2007). Following these developments, traditional economy of scarcity (of material goods) has been supplemented by a new economy of abundance (of immaterial goods). Sharing and distributing material artefacts usually decreases their value but sharing and distributing immaterial artefacts almost always increases their value (Peters and Jandrić 2019; Martínez-Cabezudo 2014). This context transcends the labour horizon, affecting our mutual interactions, our sense of own reality, and our interactions with that reality (Peters and Jandrić 2019). Postdigital mashup of material and immaterial production reaches well beyond the economic sphere to directly address the cultural, the social and the political. This type of production is biopolitical because directly affects social life as a whole, producing not only material goods but also real social relations and ways of life (Hardt and Negri 2005). Hardt and Negri's vision of biopolitics moves away from Foucault (1979) who focuses on the governance of biopower, regulatory control of the population, and constitution of discipline over the body, as the organizational axis of biopolitics. Hardt and Negri (2005) focus on biopolitics as dynamic production of knowledge where information and communication technologies, together with forms of cooperation they enable and promote, become norms of production. In the process, the network becomes the dominant mode of organization.

At the end of 1960s Debord 1967 denounced the controversial separation between spectacle and life. These days, however, spectacle and life are almost indistinguishable. The conflict between being and appearance is meaningless (Martín-Prada 2018); representation and life are unified. The postdigital perspective describes and intervenes into times and spaces where digital innovation has been already developed and now awaits for reconfiguration (Cramer 2013). At the crossroads of nature and society, different (post)digital and (post)analog forces are united in the concept of the commons. This biopolitical exercise identifies a nexus of duality that is not antagonistic but symbiotic. Enclosing biopolitics and giving in to neoliberal practices favours the loss of democracy, the loss of values that constitute human society, and by extension, the loss of our common vital space (Hess and Ostrom 2007). In relation to biopolitical production (information, culture, and knowledge), the question of commons thus becomes a question of freedom: 
When we speak of the information environment, of the cultural and symbolic space we occupy as individuals and citizens, diversification of the constraints under which we operate, including creating spaces relatively free of market-structuring laws, goes to the very heart of freedom and democracy.

(Benkler 2003: 8)

Today, production of knowledge is subordinated to the question of subsistence (Bennholdt-Thompsen 2012) and subject to biopolitical production practices. Nevertheless, our horizon is hopeful, because there are many routes to biopolitical survival and flourishing which have the potential to surpass and dismantle the domination of neoliberal rationality. These routes emerge in diverse fields from economy to social sciences; they link feminism, ecologism, social design, sciences, and many other fields of human interest; and always in beta phase. In our postdigital era of capitalist development, we face a challenge of developing new languages for describing our social relations and generating new ways of collaboration between the yesterday's mainstream and periphery (Jandrić and Hayes 2019). We need to redefine the commons in and for our postdigital age, and develop new forms of trans-disciplinary collaboration.

\section{Communniars. Journal of Image, Arts and Critical and Social Education}

One practical attempt at creating postdigital commons is the educational and research initiative the Communiars Collective. ${ }^{2}$ Founded in Sevilla, Spain, the collective develops new strategies for working with cultural commons and maintains own open access journal. Communniars. Journal of Image, Arts and Critical and Social Education $^{3}$ maintains a transversal interest in the arts (theory, criticism and creation) and critical pedagogies (the commons, international cooperation, education for development, collectives, teaching in new digital ways and contexts, learning and politics, intercreativity, non-hegemonic cultures, free culture, hacker ethic, and others) with a special wager on social transformation. Communiars develops own praxis of biopolitical theory which insists that information, methods, and pedagogies must be open to the community. This biopolitical practice of production and distribution is cooperative, collective, interdependent, and intercreative. It takes place in, and contributes to building of, the territory of the postdigital commons. While we develop various theories of postdigital commons, Communniars. Journal of Image, Arts and Critical and Social Education is a humble attempt to put some of these theories into (academic) practice.

\footnotetext{
2 https://communiars.wordpress.com/.

${ }^{3}$ Communniars. Journal of Image, Arts and Critical and Social Education is a publication promoted by Department of Art Education, University of Sevilla, Spain, and Education and Audiovisual Culture Research Group (ECAV). Journal website: http://institucional.us.es/communiars/.
} 


\section{References}

Aguilera-Klint, F. (2012). Hardin, Ostrom y los recursos de propiedad común: un desencuentro inevitable y necesario. Documentación social Revista de estudios sociales y de sociología aplicada, 165, 49-65.

Benkler, Y. (2003). The political economy of commons. Upgrade: The Europeaan Journal for the Informatics Professional, 4(3), 6-9.

Bennholdt-Thompsen, V. (2012). Subsistence: perspective for a society based on commons. In D. Bollier \& S. Hefrich (Eds.), The wealth of the commons. A world beyond market and state. Amherst. MA: Levellers Press http://wealthofthecommons.org/essay/subsistence-perspective-society-based-commons. Accessed 22 March 2019.

Brea, J. L. (2007). cultura_RAM. Barcelona: Gedisa.

Cramer, F. (2013). Post-digital aesthetics. Lemagazine. http://lemagazine.jeudepaume.org/2013/05/floriancramer-post-digital-aesthetics/. Accessed 22 Mar 2019.

Debord, G. (1967). La société du spectacle. http://classiques.uqac.ca/contemporains/debord_guy/societe_du_ spectacle/societe_du_spectacle.pdf. Accessed 22 March 2019.

Foucault, M. (1979). The history of sexuality volume 1: an introduction. London: Allen Lane.

Garcés, M. (2013). Un mundo común. Barcelona: Edicions Bellaterra.

Hardin, G. (1968). The tragedy of the commons. Science, 162(3859), 1243-1248.

Hardt, M., \& Negri, A. (2005). Multitude: war and democracy in the age of empire. London: Penguin.

Hardt, M., \& Negri, A. (2009). Commonwealth. Cambridge, MA: Harvard University Press.

Hess, C., \& Ostrom, E. (2007). Understanding knowledge as a commons. From theory to practice. Cambridge, MA: The MIT Press.

Jandrić, P. (2017). Learning in the age of digital reason. Rotterdam: Sense.

Jandrić, P., \& Hayes, S. (2019). The postdigital challenge of redefining academicpublishing from the margins. Learning, Media and Technology., 1-13. https://doi.org/10.1080/17439884.2019.1585874.

Jandrić, P., Knox, J., Besley, T., Ryberg, T., Suoranta, J., \& Hayes, S. (2019). Ciencia postdigital y educación. Communiars. Revista de Imagen, Artes y Educación Crítica y Social, 1(2), 11-21.

Laval, C., \& Dardot, P. (2014). Commun, Essai sur la révolution au XXIe siècle. Paris: La Découverte.

Marcuse, H. (1991). One-dimensional man. Studies in the ideology of advanced industrial society (2nd ed.). New York: Routledge.

Martínez-Cabezudo, F. (2014). Copyright y Copyleft. Modelos para la ecología de los saberes. Sevilla: Aconcagua.

Martín-Prada, J. (2018). El ver y las imágenes en el tiempo de Internet. Madrid: Akal.

Peters, M. A., \& Jandrić, P. (2019). Posthumanism, open ontologies and bio-digital becoming: response to Luciano Floridi's Onlife Manifesto. Educational Philosophy and Theory, 1-10. https://doi.org/10.1080 $/ 00131857.2018 .1551835$ 